\title{
Behaviour of Geopolymer Mortars after Exposure to Elevated Temperatures
}

\author{
Mehmet KAYA ${ }^{1 *}$, Mucteba UYSAL ${ }^{2}$, Kemalettin YILMAZ ${ }^{3}$, Cengiz Duran ATIS ${ }^{4}$ \\ ${ }^{1}$ Bozok University, Occupational Health and Safety Department, Yozgat 66300, Turkey \\ ${ }^{2}$ Istanbul University, Civil Engineering Department, Istanbul 34320 Turkey \\ ${ }^{3}$ Sakarya University, Civil Engineering Department, Sakarya 54187, Turkey \\ ${ }^{4}$ Erciyes University, Civil Engineering Department, Kayseri,38280, Turkey \\ crossref http://dx.doi.org/10.5755/j01.ms.24.4.18829
}

Received 14 August 2017; accepted 04 January 2018

\begin{abstract}
In this study it was investigated the behavior of class F fly ash based geopolymer mortars subjected to elevated temperatures. Geopolimer composites were prepared with CEN-sand, water, fly ash as the binder, $\mathrm{nSiO}_{2} \mathrm{Na}_{2} \mathrm{O}$ and $\mathrm{NaOH}$ mixture combination as alkali activator. After mixing fresh geopolymer mixture, prismatic specimens were prepared using $40 \mathrm{~mm} \times 40 \mathrm{~mm} \times 160 \mathrm{~mm}$ prism molds. After molding, fresh geopolymer mortar samples with their mold were subjected to heat curing at $50{ }^{\circ} \mathrm{C}, 60{ }^{\circ} \mathrm{C}, 70{ }^{\circ} \mathrm{C}, 80^{\circ} \mathrm{C}, 90^{\circ} \mathrm{C}$ and $100{ }^{\circ} \mathrm{C}$ temperature for 48 hours in an oven. After 48 hours initial heat curing, the hardened samples were taken out of their mold. Then, they were further cured by leaving them in laboratory environment at about $22 \pm 2{ }^{\circ} \mathrm{C}$ temperature, until 28 days together with heat curing duration. At the end of 28 days, geopolymer mortar samples developed flexural strength values between 2,9 $\mathrm{MPa}$ and 8,51 $\mathrm{MPa}$. Geopolymer mortar samples developed compressive strength values between 7,63 MPa and 50,64 MPa. High temperature experiments were conducted to observe behaviour of geopolymer mortars at elevated temperatures. The control cement mortar mixtures were also prepared and subjected to high temperature exposure in comparison to geopolymer mortar mixtures. Control cement mortars were cured at laboratory environment for 28 days without initial temperature curing. Control cement mortar mixtures and geopolymer mortar mixtures were exposed to elevated temperatures of $200{ }^{\circ} \mathrm{C}, 400{ }^{\circ} \mathrm{C}, 600{ }^{\circ} \mathrm{C}$ and $800{ }^{\circ} \mathrm{C}$ temperature. The unit weight, ultrasonic pulse velocity, flexural and compressive strength of all mixtures were measured before and after high temperature exposure. Scanning electron microscope (SEM) images of the mixtures were taken and $\mathrm{X}$-ray fluorescence (XRF) spectrometer analyses were carried out. It was observed that there was an increase in the flexural and compressive strengths of some geopolymer mortars after high temperature exposure. In general, geopolymer mortars exhibited better performance at elevated temperatures in comparison to control cement mortar mixture.

Keywords: geopolymer, flexural strength, compressive strength, ultrasound pulse velocity, elevated temperature.
\end{abstract}

\section{INTRODUCTION}

Cement is the most common and widely used binder material in concrete technology since the 19th century. It is easy to produce, it delivers strong and enduring concrete, it is in widespread production throughout the world, and, therefore, it seems that it will not be easily given up in the future.

As of 2014, cement production reached 4,3 billion tons [1]. Global demand is expected to reach 5.5 gigatonnes by about 2050 [2]. During cement production, clinker is heated in rotary kilns at around $1450{ }^{\circ} \mathrm{C}$. To reach such a high temperature a large amount of energy is needed. Cement production is an energy-dependent sector where $59.1 \%$ of the costs are energy costs, mainly electricity and fuel [3]. During cement production, carbon dioxide $\left(\mathrm{CO}_{2}\right)$ gas is emitted. For every ton of cement production, $900 \mathrm{~kg}$ of $\mathrm{CO}_{2}$ is emitted. Of the 30 gigametric tons of global $\mathrm{CO}_{2}$ emissions, $5 \%$ were caused by cement production [4]. Among the binder-development study alternatives to cement, geopolymer binders have turned out to be the most promising [5]. Geopolymers can be produced using natural or industrial wastes like fly ash, blast furnace slag, metakaolin (or red mud) [6].

Different binder-material production is possible using amorphous materials like fly ash or blast furnace slag containing $\mathrm{Al}_{2} \mathrm{O}_{3}, \mathrm{SiO}_{2}$ and $\mathrm{CaO}$ in their structures, with alkali activators.

As a result of the reaction of aluminosilicate fly ash with the activators, amorphous inorganic polymers, called geopolymers, are produced [7]. These materials were first discovered by Davidovits in 1975 [8]. The chemical processes behind the geopolymer structure formation are not fully understood, but there are simplified explanations of them [9]. Reactions that occur during geopolymerization can be summarized in three fundamental steps:

a. Dissolution of aluminosilicate solids: Aluminosilicates that are found in pozzolanic solids are dissolved in alkali activators with a high $\mathrm{pH}$. So, silicate, aluminate and aluminosilicate structures are formed.

b. Gel formation: The species diffused during dissolution are kept in a watery phase. This oversaturated aluminosilicate solution forms a gel, where its oligomers form long chains and webs. At this level, a porous and watery structure are observed.

c. Polycondensation: The particles in the gel keep on organizing, resulting in an even bigger web. Finally, a three dimensional geopolymer structure is formed [10]. To activate the fly ash, alkali activators are used, such as sodium hydroxide $(\mathrm{NaOH})$ [11-13], potassium

\footnotetext{
* Corresponding author. Tel.: +90-354-2421023; fax: +90-354-2421038.

E-mail address: mehmet.kaya@bozok.edu.tr (M. Kaya)
} 
hydroxide $(\mathrm{KOH})[14]$, sodium silicate $\left(\mathrm{nSiO}_{2} \mathrm{Na}_{2} \mathrm{O}\right)$ [1516], potassium silicate $\left(\mathrm{nK}_{2} \mathrm{SiO}_{3}\right)$ [17], calcium hydroxide $\left(\mathrm{Ca}(\mathrm{OH})_{2}\right)$ [18]. The most common method in order to obtain a geopolymer with high endurance is to mix $\mathrm{NaOH}$ and $\mathrm{nSiO}_{2} \mathrm{Na}_{2} \mathrm{O}$ at certain ratios [10]. By increasing the density of activator within the geopolymer mixture, up to a certain degree, an increase in the compressive strength of the geopolymer is observed [17]. The most important aspect in mixing $\mathrm{NaOH}$ and $\mathrm{nSiO}_{2} \mathrm{Na}_{2} \mathrm{O}$ at certain ratios is the tuning of the $\mathrm{SiO}_{2} / \mathrm{Na}_{2} \mathrm{O}$ ratio, called the silica modulus (Ms) [19]. Increasing the Ms ratio by a certain amount increases the endurance; however, the ability to process it decreases due to the geopolymer structure formed [20]. Geopolymer is analogous to traditional Portland cement in terms of usage. There are differences between the two considering the costs, chemical composition and endurance mechanisms [21]. Alkalis, the main source of geopolymers, can be classified as caustic alkalis $(\mathrm{MOH})$, silicates $\left(\mathrm{M}_{2} \mathrm{O} . \mathrm{nSiO}_{2}\right)$, weak acidic salts $\left(\mathrm{M}_{2} \mathrm{CO}_{3}, \mathrm{M}_{2} \mathrm{SO}_{3}, \mathrm{M}_{3} \mathrm{PO}_{4}\right.$, etc.), aluminates $\left(\mathrm{M}_{2} \mathrm{O} \cdot \mathrm{nAl}_{2} \mathrm{O}_{3}\right)$, aluminosilicates $\left(\mathrm{M}_{2} \mathrm{O} . n \mathrm{Al}_{2} \mathrm{O}_{3}\right.$.(2-6). $\left.\mathrm{SiO}_{2}\right)$ and strong acidic salts $\left(\mathrm{M}_{2} \mathrm{SO}_{4}\right)$ [22]. Cement paste, once stiffened, cannot be used as a binder for refractory material production because it contains $\mathrm{C}-\mathrm{S}-\mathrm{H}$ gels that have water in their structures.

$\mathrm{N}-\mathrm{A}-\mathrm{S}-\mathrm{H}$ gels that are present in the main structures of geopolymers do not contain water. Water is used in the mixing of geopolymers for processing, and it leaves the structure during drying to leave discontinuous, small voids. This gives the geopolymer numerous advantages, such as lightness, heat insulation and fire resistance [23]. Irrespective of the characteristics of the fly ash used, geopolymers produced via activation are always amorphous. Usually, the highest endurance is attained with activators containing sodium silicate. Additionally, it was determined that compressive strength increases with an increasing $\mathrm{SiO}_{2} / \mathrm{Na}_{2} \mathrm{O}$ mass ratio and $\mathrm{Si} / \mathrm{Al}$ atomic ratio, and high compressive strength is related directly to the $\mathrm{Si} / \mathrm{Al}$ atomic ratio [24]. Different reaction products like microstructured aluminosilicate gel have been observed as a result of the activation of fly ash with alkali activators [22]. Behavior of the geopolymer, fresh or stiffened, depends on the fly ash type, particle distribution, mineralogical composition and increasing sodium silicate mixing ratio [25]. As stated in other literature, water/geopolymer and activator/fly ash ratios have a direct effect on the compressive strength and ability to be processed; nevertheless, the fluid alkali/water ratio is the most significant parameter affecting the geopolymer strength [26].

Geopolymers are appropriate for producing acoustic equipment, thermal panels and light prefabricated components [27]. For fly ash activated with alkali, an appropriate temperature and high alkali ratio must be provided [10]. Compressive and flexural strengths of geopolymer mortars are higher with respect to mortars using Portland cement. In addition to having better performance at higher temperatures, geopolymers produced with fly ash also have a higher freeze-thaw resistance [28]; however, it is observed that, with increasing porous structure, freezethaw resistance decreases [20]. Geopolymer mortars also have a higher abrasive strength compared to traditional mortars [28]. Geopolymer mortars have a lower drying shrinkage with respect to traditional ones, and their sulfate resistance is also lower. Additionally, it has been determined that their rapid chloride permeability is higher than traditional mortars [19-29].

It is believed that the binding properties of the geopolymers originate from the three-dimensional N-A-S$\mathrm{H}$ gel in the structure. This gel is very resistant to high temperatures. X-ray diffraction (XRD) analyzes and Nuclear magnetic resonance (NMR) results show that the geopolymer structure does not deteriorate up to $600{ }^{\circ} \mathrm{C}$ [30]. In cementitious composites, due to the decomposition of calcium hydroxide $(\mathrm{CH})$ and calcium silicate hydrates (CSH) as a result of high temperature effect, water is lost and the internal structure is deteriorated [31]. Depending on the differences in chemical structures, the geopolymer is thought to have a higher temperature resistance than conventional cement mortars $[32,33]$. In this study, geopolymer mortar and cement-binder control samples were compared to show that the high temperature resistances of the geopolymer mortars are better than the cement-bound mortars.

\section{MATERIALS AND METHODOLOGY}

\subsection{Materials}

The scanning electron image (SEM) of Tuncbilek Class F fly ash are presented in Fig. 1. In the SEM image, the surface of the fly ash particles is observed to contain irregular voids.

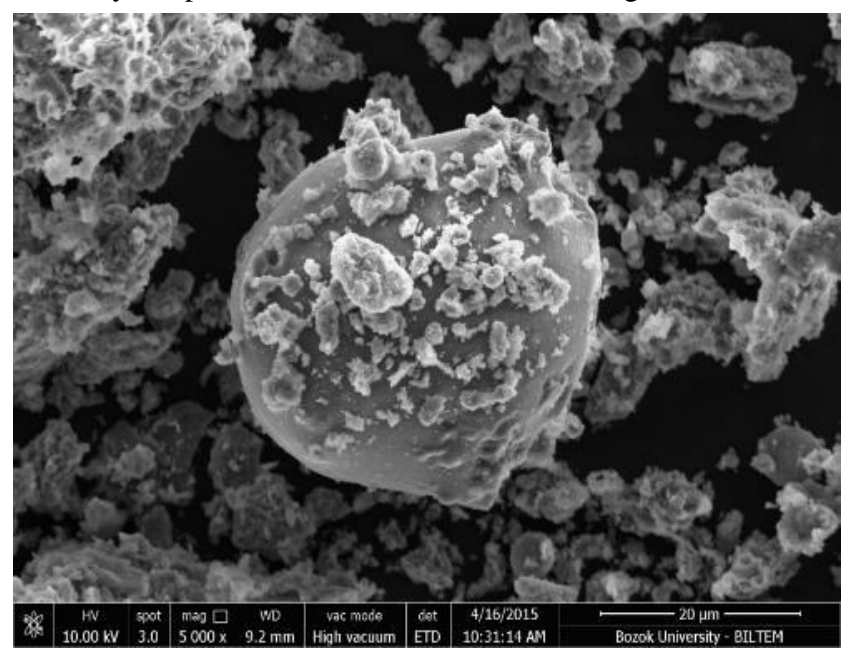

Fig. 1. SEM image of Tunçbilek Class F type of fly ash (x5000)

Tap water used was obtained from the city waterworks of Yozgat for the production of geoplymer mortars during the experimental procedure. Sand used in the research program was of standard Rilem Cembureau type with maximum aggregate size of $2 \mathrm{~mm}$ according to TS EN 1971: 2012 [31].

In Fig. 2, Standard sand grading and limit values are given. According to EN 197-1 [35], Portland cement (CEM I 42.5 R) was used in control mixtures. Specific surface area by Blaine and 28th day compressive strength of cement was $333.1 \mathrm{~m}^{2} / \mathrm{kg}$, and $54.7 \mathrm{MPa}$, respectively.

Fly ash is used in this study was procured from Tuncbilek power plant and can be classified as Class $\mathrm{F}$ according to ASTM C 618 [30]. The physical and chemical properties of Class F fly ash and Portland cement used in this study are presented in Table 1 . 


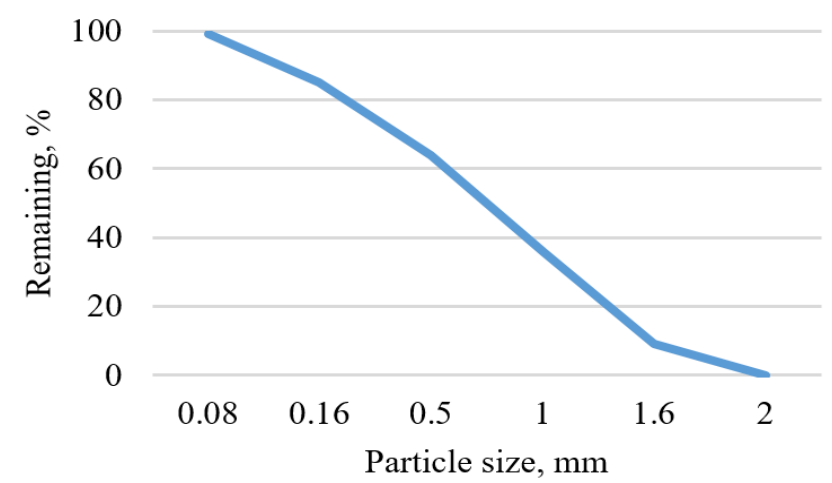

Fig. 2. Standard sand grading

Table 1. Physical and chemical properties of F fly ash

\begin{tabular}{|l|c|c|}
\hline Properties & Fly ash & CEM I 42.5R \\
\hline Chemical properties & $\%$ & $\%$ \\
\hline $\mathrm{MgO}$ & 3.68 & 2.3 \\
\hline $\mathrm{Al}_{2} \mathrm{SO}_{3}$ & 21.41 & 5.70 \\
\hline $\mathrm{SiO}_{2}$ & 58.73 & 18.60 \\
\hline $\mathrm{SO}_{3}$ & 0.25 & 2.73 \\
\hline $\mathrm{Na}_{2} \mathrm{O}$ & 0.28 & 0.2 \\
\hline $\mathrm{Ka} 2 \mathrm{O}$ & 1.65 & 1.2 \\
\hline $\mathrm{CaO}$ & 1.88 & 62.60 \\
\hline $\mathrm{Fe}_{2} \mathrm{SO}_{3}$ & 10.46 & 3.1 \\
\hline Insoluble residues & 24.33 & 0.70 \\
\hline $\mathrm{Loss}$ on ignition & 0.64 & 2.9 \\
\hline $\mathrm{Cl}$ & - & 0.01 \\
\hline Free CaO & - & 0.70 \\
\hline Physical properties & & - \\
\hline Specific weight, ton/m & & 3.10 \\
\hline 45 micron sieve balance, $\%$ & 2.24 & - \\
\hline Blaine specific surface, $\mathrm{cm}^{2} / \mathrm{gm}$ & 3703 & 3331 \\
\hline Initial Setting, min & - & 160 \\
\hline End of setting, min & - & 210 \\
\hline Volume expansion, mm & - & 0.70 \\
\hline
\end{tabular}

\subsection{Methodology}

All the geopolymer samples are produced without cement. The mixing ratios of the geopolymer samples are given in Table 2. They are prepared in a standard mortar mixer (Fig. 3).

Table 2. Mixing ratio of the samples

\begin{tabular}{|l|c|c|c|c|c|c|}
\hline Sample, gr & $\begin{array}{c}\text { Fly } \\
\text { ash }\end{array}$ & Cement & Sand & Water & $\mathrm{NaoH}$ & $\mathrm{Na}_{2} \mathrm{SiO}_{3}$ \\
\hline Geopolymer & 450 & - & 1175 & 45 & 99 & 71 \\
\hline Control & - & 450 & 1350 & 225 & - & - \\
\hline
\end{tabular}

First, the sand and fly ash were mixed dry, at a slow rotating speed, for about 60 seconds. Then, a mixed and cooled solution of $\mathrm{NaOH}, \mathrm{Na}_{2} \mathrm{SiO}_{3}$ and water $(14 \% \mathrm{Na}$ in weight and $\mathrm{Ms}=0.2$ ) was added to the mixer and mixed for 90 seconds at a slow rotating speed. Finally, a fast rotating speed mixing was performed for 90 seconds. Geopolymers from the mixer were placed in standard molds with dimensions of $40 \times 40 \times 160 \mathrm{~mm}$. The molded samples were placed in a dry incubator. Every sample group was coded separately according to their temperature cure: F50 for $50{ }^{\circ} \mathrm{C}, \mathrm{F} 60$ for $60{ }^{\circ} \mathrm{C}, \mathrm{F} 70$ for $70{ }^{\circ} \mathrm{C}, \mathrm{F} 80$ for $80{ }^{\circ} \mathrm{C}, \mathrm{F} 90$ for $90{ }^{\circ} \mathrm{C}$ and $\mathrm{F} 100$ for $100{ }^{\circ} \mathrm{C}$. Each group was kept at their respective temperature of $50^{\circ} \mathrm{C}, 60{ }^{\circ} \mathrm{C}, 70^{\circ} \mathrm{C}, 80^{\circ} \mathrm{C}, 90^{\circ} \mathrm{C}$ and $100{ }^{\circ} \mathrm{C}$ for 48 hours. Samples, out of the incubator, were cure in the open, at room temperature $22 \pm 2{ }^{\circ} \mathrm{C}$ for 28 days. The cement binder control samples were removed from mold 24 hours after production and stored in a pool of $20 \pm 2{ }^{\circ} \mathrm{C}$ for 28 days.

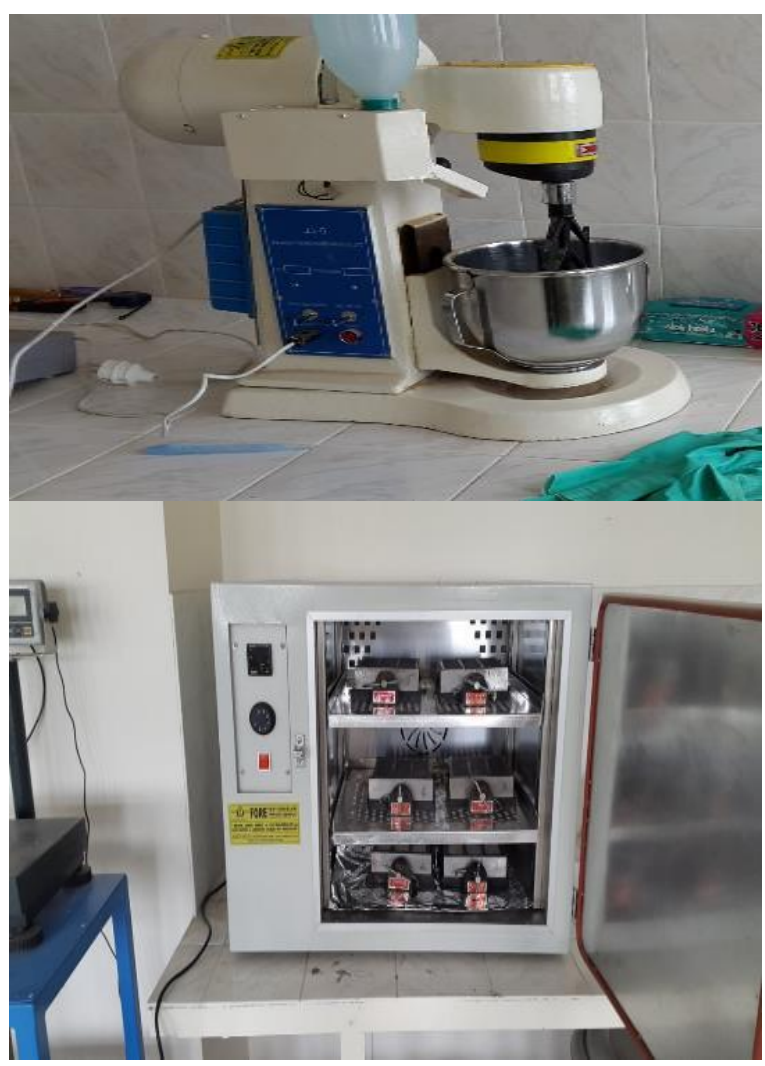

Fig. 3. The molding and curing of geopolymer

The mixing ratios of the cement-binder control samples that were prepared in order to compare with the geopolymer samples in a high-temperature experiment, are given in Table 3. Control samples were produced according to the principles given in TS 196-1: 2016 [36] and were compacted in standard molds with dimensions of $40 \times 40 \times 160 \mathrm{~mm}$. Stiffened samples were removed from the molds and kept in curing pools for 28 days.

The unit weight and ultrasonic pulse velocity of the samples (of dimensions $40 \times 40 \times 160 \mathrm{~mm}$ ) were measured according to the principles stated in TS EN 1250-4 [37] and then exposed to elevated temperature according to the TS EN 1363-2 [38] fire resistance experiment standards (Fig. 4).



Fig. 4. Ultrasonic pulse velocity tester 
Then the flexural and compressive strengths of every sample produced for the different temperature groups (F50, F60, F70, F80, F90, F100 and control) were measured. The flexural test was carried out with a $100 \mathrm{~mm}$ opening according to TS EN 1015-11 [39] standard and a single point load-controlled loading facility. The compressive test was carried out by loading from the side surfaces of 6 prisms obtained by fracture of 3 specimens subjected to flexural test according to TS EN 1015-11 standard. Applying elevated temperature for the samples are given Fig. 5.

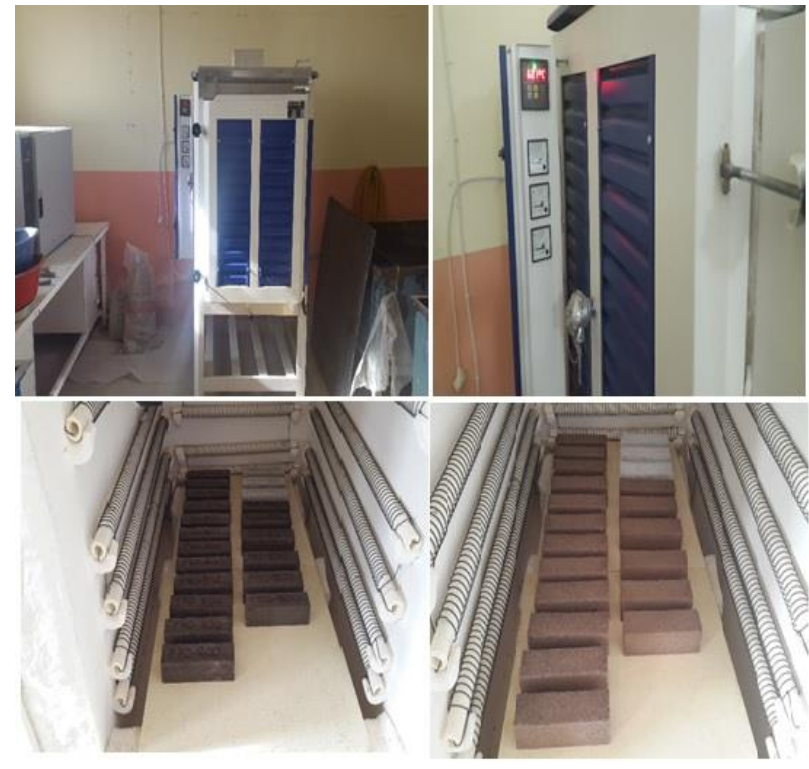

Fig. 5. Applying elevated temperature for the sample

Samples from every temperature group were exposed to heat separately at $200{ }^{\circ} \mathrm{C}, 400{ }^{\circ} \mathrm{C}, 600{ }^{\circ} \mathrm{C}$ and $800{ }^{\circ} \mathrm{C}$ for one hour (Fig. 5). The temperature increase ratio of the high-temperature oven was set at $7{ }^{\circ} \mathrm{C} / \mathrm{min}$. After elevated temperature exposure, samples were kept at room temperature for 24 hours in a laboratory to cool down. After heating, the unit weight and ultrasonic pulse velocity of the samples were measured and their flexural and compressive strengths were tested in order to compare with the strength values before heating.

\section{EXPERIMENTAL RESULTS}

Flexural strengths of the samples both before and after elevated temperature exposure are given in Fig. 6. Examining the flexural strength, it is seen that F50 (the sample cured at $50{ }^{\circ} \mathrm{C}$ ) has a higher flexural strength with respect to the other geopolymer and cement control samples for exposures at $200^{\circ} \mathrm{C}, 400{ }^{\circ} \mathrm{C}, 600^{\circ} \mathrm{C}$ and $800^{\circ} \mathrm{C}$. Beyond $800{ }^{\circ} \mathrm{C}$, the flexural strength of the F50 sample was still higher, whereas flexural strength of other samples decreased. Since the reaction of the activator in the cured geoplymer sample at $50{ }^{\circ} \mathrm{C}$ was not complete, the strength increased after high temperature. Additionally, all of the geopolymer samples produced with class F fly ash had a higher flexural strength compared to the cement-binder control sample.

Flexural strength of the F50 sample was $2.96 \mathrm{MPa}$. It reached $6.63 \mathrm{MPa}$ after heating at $200{ }^{\circ} \mathrm{C}$ and $3.48 \mathrm{MPa}$ at $800{ }^{\circ} \mathrm{C}$. The F100 no-cement sample (cured at $100{ }^{\circ} \mathrm{C}$ ), which had a flexural strength of $8.03 \mathrm{MPa}$ before heating, exhibited a $70.8 \%$ loss after being heated at $800{ }^{\circ} \mathrm{C}$ with a final flexural strength of $2.34 \mathrm{MPa}$.

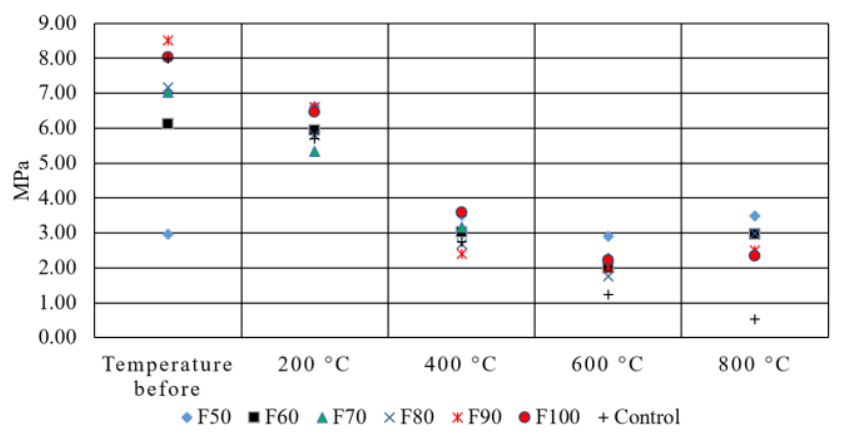

Fig. 6. Effect of elevated temperatures on the flexural strength of the samples

The control sample, which had a flexural strength of $7.98 \mathrm{MPa}$ before heating, exhibited a $93.48 \%$ loss after being heated at $800{ }^{\circ} \mathrm{C}$ with a final flexural strength of $0.52 \mathrm{MPa}$. In general, flexural strength of class F fly ash geopolymers are higher than that of the cement control group after the effects of elevated temperature.

There is not enough temperature to reach the inside of the samples cured at low temperature. For this reason, the activation process is not fully realized. Samples cured at low temperatures complete the remaining activation when subjected to high temperatures resulting in increased strength at high temperatures. The samples produced by curing at low temperature show more resistance to high temperature than the samples produced by curing at high temperature. In a study investigating the flexural strength of geopolymers, the geopolymer at $600{ }^{\circ} \mathrm{C}$ showed a fire resistance as high as $120 \%$ of the original flexural strength [40]. Another study on the geopolymer indicated that it is the development of strength at high temperatures. At $600{ }^{\circ} \mathrm{C}$, the geopolymer compressive strength reached $110 \%$ of its original strength [41]. The compressive strengths of the geopolymer samples after elevated temperature exposure are higher than the compressive strength of the cement control sample. Previous studies have shown that high temperature resistances of geopolymer mortars are higher than cement-bonded mortars [32, 33]. The compressive strengths of the geopolymer samples cured at $50^{\circ} \mathrm{C}, 60^{\circ} \mathrm{C}$ and $70^{\circ}$ (F50, F60 and F70), were increased after heating at $800{ }^{\circ} \mathrm{C}$. Since the reaction of the activator in the cured geoplymer samples at F50, F60 and F70 was not complete, the strength increased after high temperature. The compressive strength of the F50 sample, after heating at $800{ }^{\circ} \mathrm{C}$, increased from $7.63 \mathrm{MPa}$ to $40.70 \mathrm{MPa}$, whereas the compressive strength of the F60 sample increased from 18.63 $\mathrm{MPa}$ to $33.94 \mathrm{MPa}$, and the compressive strength of the F70 sample increased from 28.38 $\mathrm{MPa}$ to $32.35 \mathrm{MPa}$. The F90 sample had a compressive strength loss of $16.64 \%$ and F100 had a loss of $26.31 \%$ after being heated at $800{ }^{\circ} \mathrm{C}$, whereas the compressive strength of the cement control sample decreased by $68,83 \%$. In general, compressive strengths of geopolymers after the effects of elevated temperature are higher in comparison with the control samples. Compressive strengths of the samples under the effects of elevated temperature are given in Fig. 7. 


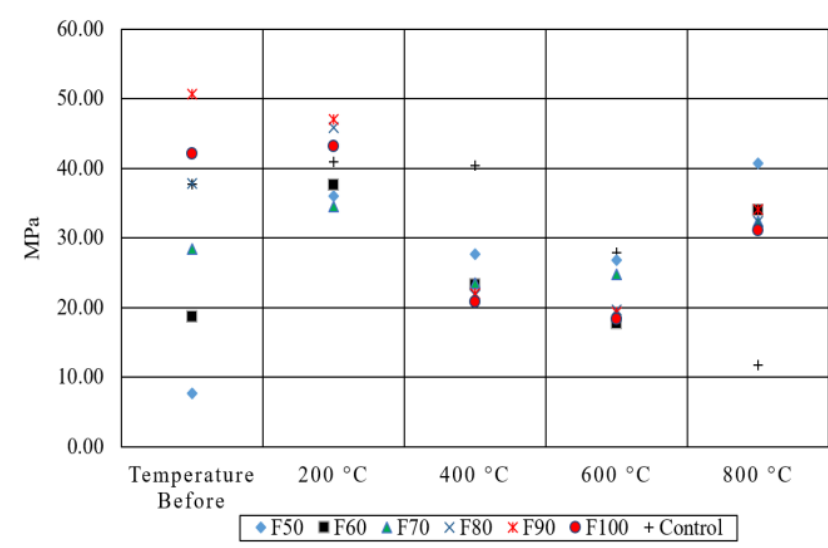

Fig. 7. Effect of elevated temperatures on the compressing strength of the samples

Weight loss of the samples under the elevated temperature exposure are given in Fig. 8.

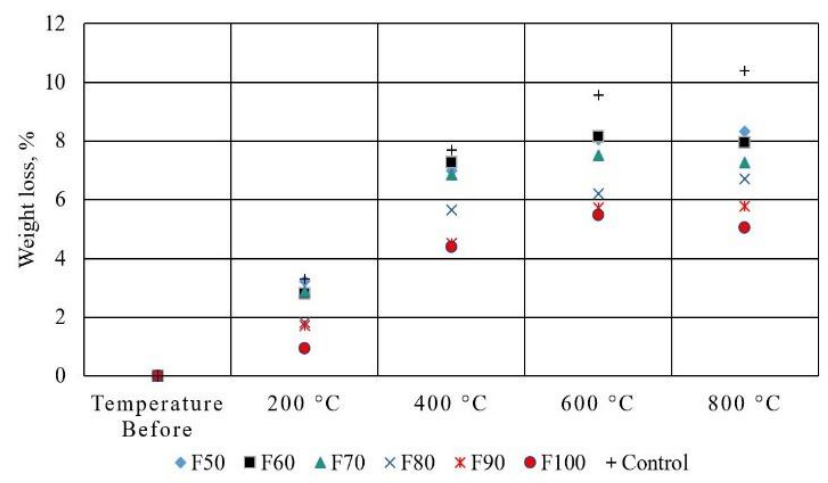

Fig. 8. The influence of elevated temperatures on weight loss of the samples

It is seen that the weight loss of the samples under the effects of elevated temperature are less for the samples with a higher treatment temperature. Weight losses of the geopolymers cured at low temperature, are greater than the weight losses of the no-cement samples cured at high temperatures. The weight loss of the geopolymer samples cured at $50{ }^{\circ} \mathrm{C}$ after the effects of high temperature at $800{ }^{\circ} \mathrm{C}$ was $8.32 \%$, whereas the weight loss of geopolymers cured at $100{ }^{\circ} \mathrm{C}$ was $5.05 \%$. The control sample had a weight loss of $10.39 \%$ after $800{ }^{\circ} \mathrm{C}$ exposure. In general, geopolymer samples have a smaller weight loss than cement-binder samples.

At higher temperatures, there was a decrease in ultrasound pulse velocity due to the increase in void ratio owing to the disappearance of water and internal structure deterioration of the samples.

Decreasing ratios in the ultrasonic pulse velocity of the samples, after heating, are given in Fig. 9. There was a decrease in the ultrasonic pulse velocity of all samples after elevated temperature exposure. The decrease in the ultrasonic pulse velocity of the geopolymer samples that are cured at $50{ }^{\circ} \mathrm{C}, 60^{\circ} \mathrm{C}$ and $70^{\circ} \mathrm{C}$ were smaller than the control sample.

The decrease in ultrasonic pulse velocity of the F50 sample (cured at $50{ }^{\circ} \mathrm{C}$ ) after heat exposure at $800{ }^{\circ} \mathrm{C}$ was $41.08 \%$, whereas the decrease in ultrasonic pulse velocity of the F100 sample (cured at $100{ }^{\circ} \mathrm{C}$ ) was $63.75 \%$. For the control sample, the decrease after heating at $800{ }^{\circ} \mathrm{C}$ was determined to be $56.66 \%$. In general, the ratio of decrease in the ultrasonic pulse velocity for the geopolymer samples cured at temperatures up to $90{ }^{\circ} \mathrm{C}$ is low, which means that the porous structure did not increase and structural deteriorations are less common. The observed increase on flexural and compressive strengths after exposure to elevated temperature which the geopolymer samples were produced by curing at low temperatures could be the due to the fact that the $\mathrm{NaOH}+\mathrm{Na}_{2} \mathrm{SiO}_{3}$ compound did not activated in the mixture during the production process. Luga has investigated the behaviour of geopolymer of fly ash mortars under the elevated temperature and reported that the geoplymer samples which exposed to elevated temperature at $300{ }^{\circ} \mathrm{C}, 600{ }^{\circ} \mathrm{C}$ and $900{ }^{\circ} \mathrm{C}$ showed better performance two times as values of flexural strength than the samples which containing cement as binder after elevated temperature exposure [42].

It was also reported that compressive strength loss of the geoplymer samples was about in the range of $40 \%-70 \%$ and the samples containing cement as binder showed compressive strength loss in the range of $80 \%-90 \%$. It was also stated that the weight loss of the geoplymer samples was $30 \%$ less for the samples which containing cement as binder [41]. Gorur stated that the geoplymer samples which containing fly ash, sand, water and $\mathrm{NaOH}$ demonstrated better performance as compressive and flexural strength than the samples containing cement as binder after elevated temperature exposure [28]. Tanyildizi et al. have investigated mechanical properties of geopolymer concrete containing polyvinyl alcohol fiber exposed to high temperature. They reported that the samples that were cured at $60{ }^{\circ} \mathrm{C}$ indicated the best results in compressive strength and flexural strength among the samples that were cured at $60{ }^{\circ} \mathrm{C}, 80{ }^{\circ} \mathrm{C}$, and $100{ }^{\circ} \mathrm{C}$. In their study, as the temperatures increased, flexural strength and compressive strength of most samples decreased. However, the compressive strength of geopolymer concrete that was cured at $60{ }^{\circ} \mathrm{C}$ and exposed to $400{ }^{\circ} \mathrm{C}$ temperature increased $29 \%$ with respect to the control sample. The flexural strength behavior of the samples a similar increase like the compressive strength at $400{ }^{\circ} \mathrm{C}$. The flexural strength increased about $45 \%$ with respect to the control sample [43]. Kong et al. have investigated comparative performance of geopolymers made with fly ash and metakaolin after exposure to elevated temperatures. They used both types of geopolymers were synthesized with sodium silicate and potassium hydroxide solutions. They reported that, both geopolymers showed weight loss with temperature increase. An average weight loss of $11 \%$ after temperature exposure was recorded for the fly ash geopolymer; which was remarkably lower than that of the metakaolin geopolymer which is $30 \%$ weight loss. This weight loss is assumed to be due to loss of evaporable water. Geopolymers based on fly ash improved an increase in compressive strength at least the order of $6 \%$ after elevated temperature exposure and some degree of sintering appears to occur at elevated temperatures, thus increasing the compressive strength [44].

The amount of water contained in the samples cured at low temperature is more than the amount of water in samples cured at high temperature. For this reason, after the high temperature effect, the F50-F60-F70 samples lose 
more weight than the F80-F90-F100 samples. Decreasing ratios in the ultrasonic pulse velocity of the samples, after heating, are given in Fig. 9

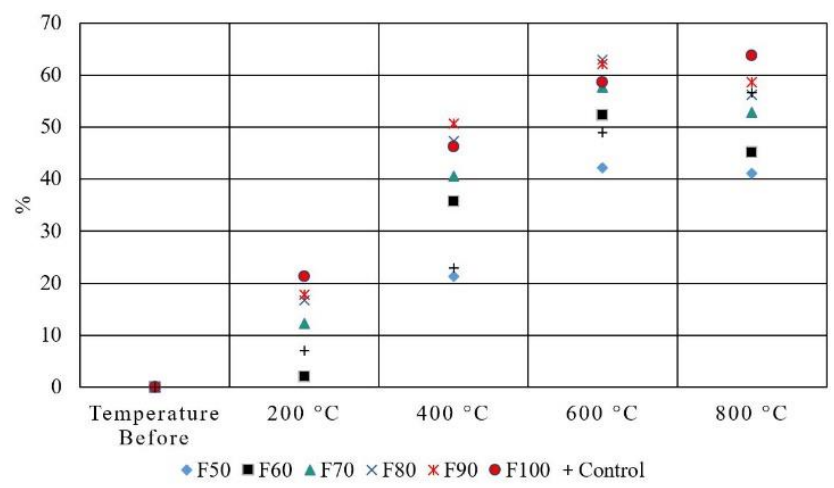

Fig. 9. The influence of elevated temperatures on the reduction ultrasonic velocity pulse ratios of the samples

There was a decrease in the ultrasonic pulse velocity of all samples after elevated temperature exposure. The decrease in the ultrasonic pulse velocity of the geopolymer samples that are cured at $50{ }^{\circ} \mathrm{C}, 60{ }^{\circ} \mathrm{C}$ and $70{ }^{\circ} \mathrm{C}$ were smaller than the control sample. The decrease in ultrasonic pulse velocity of the $\mathrm{F} 50$ sample (cured at $50{ }^{\circ} \mathrm{C}$ ) after heat exposure at $800{ }^{\circ} \mathrm{C}$ was $41.08 \%$, whereas the decrease in ultrasonic pulse velocity of the F100 sample (cured at $100^{\circ} \mathrm{C}$ ) was $63.75 \%$. For the control sample, the decrease after heating at $800{ }^{\circ} \mathrm{C}$ was determined to be $56.66 \%$. In general, the ratio of decrease in the ultrasonic pulse velocity for the geopolymer samples cured at temperatures up to $90{ }^{\circ} \mathrm{C}$ is low, which means that the porous structure did not increase and structural deteriorations are less common.

The samples used in flexural and compressive strength tests were also scanned microscope. Scanning electron microscope (SEM) images for geopolymer sample (F90), which was produced using class $\mathrm{F}$ fly ash with activators containing $14 \% \mathrm{Na}, \mathrm{Ms}=0.2$, at $90{ }^{\circ} \mathrm{C}$ for 48 hours, are given in Fig. 10.

XRF analysis test results of sample (F90) with activators containing $14 \% \mathrm{Na}, \mathrm{Ms}=0.2$, at $90^{\circ} \mathrm{C}$ for 48 hours, are given in Table 3.

Table 3. XRF analysis test results of the sample FN14M2

\begin{tabular}{|c|c|c|}
\hline Composition & $\mathrm{m} / \mathrm{m} \%$ & Standart error, $\%$ \\
\hline $\mathrm{SiO}_{2}$ & 69.84000 & 0.23000 \\
\hline $\mathrm{Al}_{2} \mathrm{O}_{3}$ & 10.86000 & 0.16000 \\
\hline $\mathrm{Na}_{2} \mathrm{O}$ & 9.94000 & 0.15000 \\
\hline $\mathrm{Fe}_{2} \mathrm{O}_{3}$ & 3.98000 & 0.10000 \\
\hline $\mathrm{K}_{2} \mathrm{O}$ & 1.72000 & 0.07000 \\
\hline $\mathrm{MgO}$ & 1.52000 & 0.06000 \\
\hline $\mathrm{CaO}$ & 0.89100 & 0.04400 \\
\hline $\mathrm{TiO}_{2}$ & 0.42800 & 0.02100 \\
\hline $\mathrm{SO}_{3}$ & 0.14700 & 0.00700 \\
\hline $\mathrm{Cr}_{2} \mathrm{O}_{3}$ & 0.11100 & 0.00600 \\
\hline
\end{tabular}

Scanning electron microscope (SEM) images for geopolymer sample after $800{ }^{\circ} \mathrm{C}$ temperature exposure (F90-800), which was produced using class $\mathrm{F}$ fly ash with activators containing $14 \% \mathrm{Na}, \mathrm{Ms}=0.2$, at $90{ }^{\circ} \mathrm{C}$ for 48 hours, are given in Fig. 11.

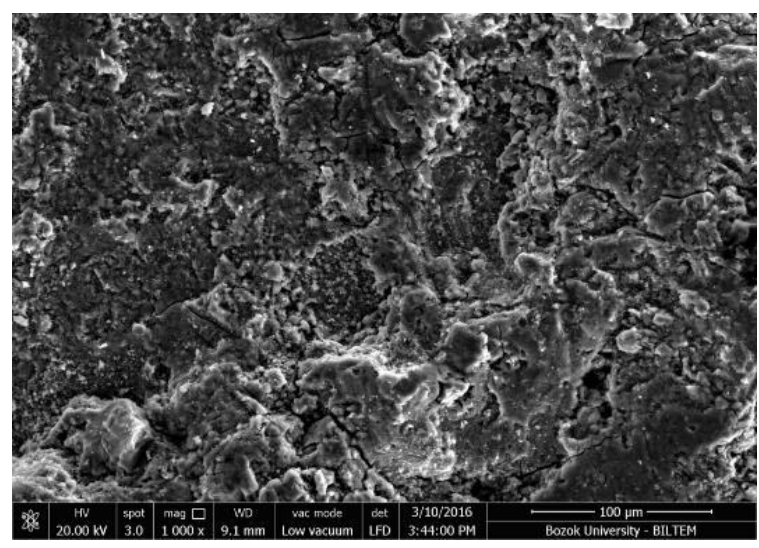

a

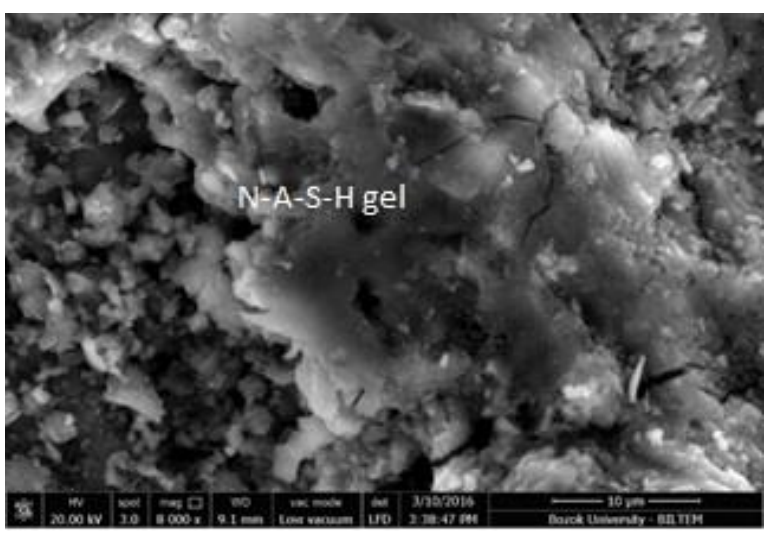

b

Fig. 10. $a-$ SEM image of the sample F90; b-SEM image of the sample after flexural and compressive tests F90

Scanning electron microscope (SEM) images for geopolymer sample after $800{ }^{\circ} \mathrm{C}$ temperature exposure (F50-800), which was produced using class $\mathrm{F}$ fly ash with activators containing $14 \% \mathrm{Na}, \mathrm{Ms}=0.2$, at $50{ }^{\circ} \mathrm{C}$ for 48 hours, are given in Fig. 12.

Scanning electron microscope (SEM) images for control sample was used Portland cement after $800{ }^{\circ} \mathrm{C}$ temperature exposure are given in Fig. 13. SEM images revealed that the inner structural deteriorations are less in the geopolymer samples compared to cement the control samples. In the SEM images, there are gaps in the control sample where the internal structure is distorted at $800{ }^{\circ} \mathrm{C}$. $\mathrm{XRF}$ analysis test results of geoplymer sample after $800{ }^{\circ} \mathrm{C}$ temperature exposure (F90-800) with activators containing $14 \% \mathrm{Na}, \mathrm{Ms}=0.2$, at $90{ }^{\circ} \mathrm{C}$ for 48 hours, are given in Table 4.

Table 4. XRF analysis test results of the sample F90-800

\begin{tabular}{|c|c|c|}
\hline Composition & $\mathrm{m} / \mathrm{m} \%$ & Standart error, $\%$ \\
\hline $\mathrm{SiO}_{2}$ & 71.53000 & 0.23000 \\
\hline $\mathrm{Al}_{2} \mathrm{O}_{3}$ & 10.52000 & 0.15000 \\
\hline $\mathrm{Na}_{2} \mathrm{O}$ & 8.98000 & 0.14000 \\
\hline $\mathrm{Fe}_{2} \mathrm{O}_{3}$ & 3.68000 & 0.09000 \\
\hline $\mathrm{K}_{2} \mathrm{O}$ & 1.62000 & 0.06000 \\
\hline $\mathrm{MgO}$ & 1.60000 & 0.06000 \\
\hline $\mathrm{CaO}$ & 0.94700 & 0.04700 \\
\hline
\end{tabular}






$\mathrm{a}$

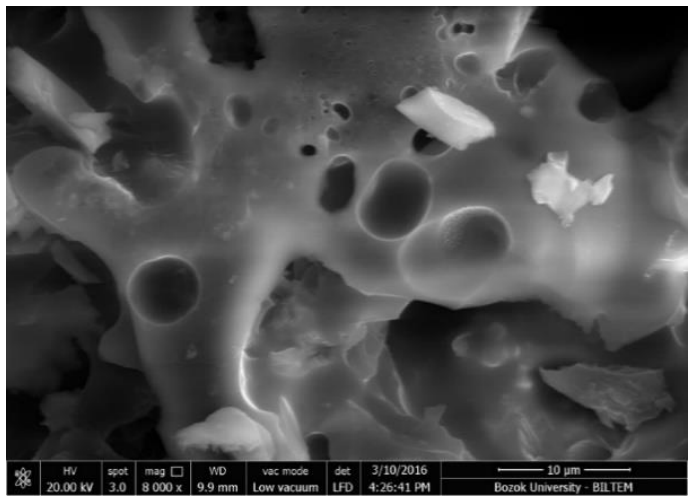

$\mathrm{b}$

Fig. 11. a-SEM image of F90-800 sample after exposure to $800{ }^{\circ} \mathrm{C}$ temperature; $\mathrm{b}-\mathrm{SEM}$ image of $\mathrm{F} 90-800$ sample after exposure to $800{ }^{\circ} \mathrm{C}$ temperature

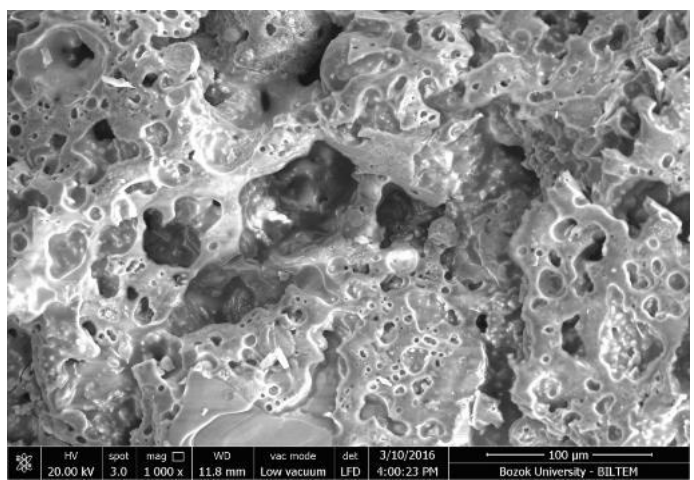

a

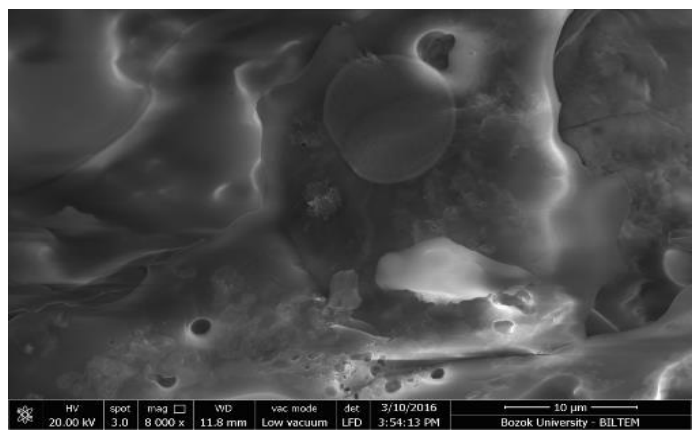

b

Fig. 12. a-SEM image of F50-800 sample after exposure to $800{ }^{\circ} \mathrm{C}$ temperature; $\mathrm{b}$-SEM image of F50-800 sample after exposure to $800{ }^{\circ} \mathrm{C}$ temperature
XRF analysis test results of geoplymer sample after $800{ }^{\circ} \mathrm{C}$ temperature exposure (F50-800) with activators containing $14 \% \mathrm{Na}, \mathrm{Ms}=0.2$, at $50{ }^{\circ} \mathrm{C}$ for 48 hours, are given in Table 5. XRF analysis shows that the amount of $\mathrm{SiO}_{2}$ in the $\mathrm{F} 50$ sample after $800{ }^{\circ} \mathrm{C}$ is higher than the amount of $\mathrm{SiO}_{2}$ in the sample $\mathrm{F} 90$. This confirms that the strength mechanism of the F50 sample is greater than the F90 sample. $\mathrm{SiO}_{2}$ is effective on the mechanism of the geopolymer. Recent studies have shown that the $\mathrm{SiO}_{2}$ additive improves the compactness and robustness of the gepolymer $[45,46]$. The increase of $\mathrm{SiO}_{2}$ in XRF results and the N-A-S-H saturated gel structure in SEM images supports the mechanism of increase strength.
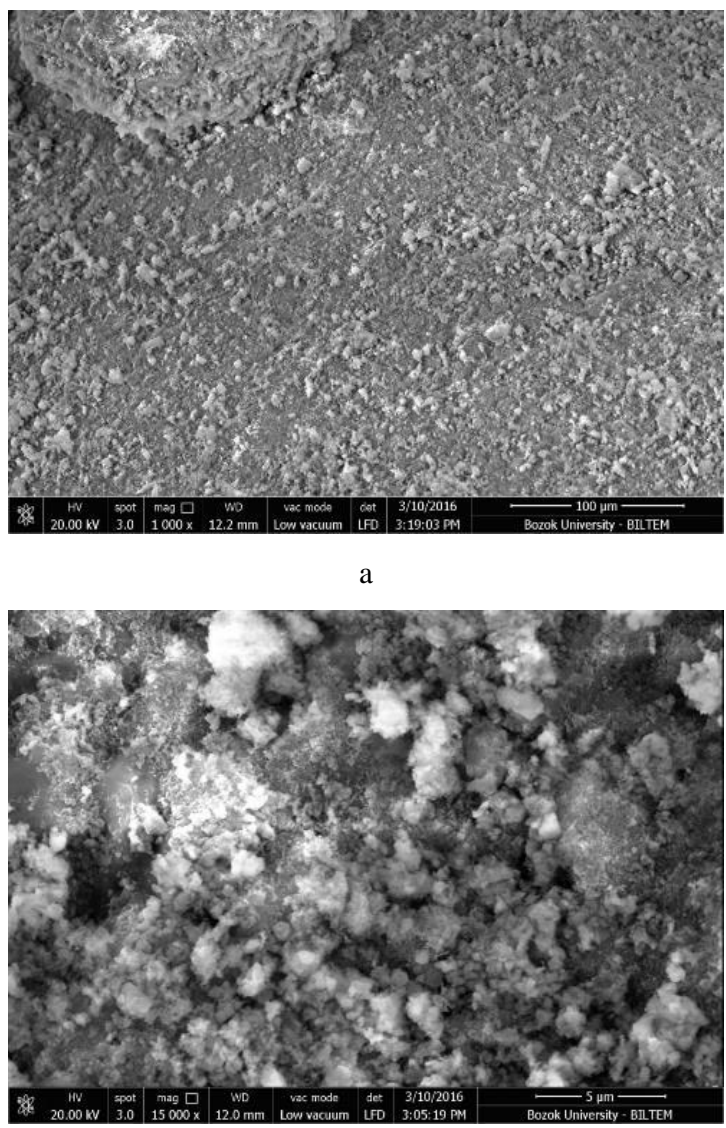

Fig. 13. a-SEM image of the control sample after exposure of $800{ }^{\circ} \mathrm{C}$ temperature; $\mathrm{b}-\mathrm{SEM}$ image of deterioration internal structure of control sample after exposure of $800{ }^{\circ} \mathrm{C}$ temperature

Table 5. XRF analysis test results of the sample F50-800

\begin{tabular}{|c|c|c|}
\hline Composition & $\mathrm{m} / \mathrm{m} \%$ & Standart error, \% \\
\hline $\mathrm{SiO}_{2}$ & 76.08000 & 0.21000 \\
\hline $\mathrm{Al}_{2} \mathrm{O}_{3}$ & 8.15000 & 0.14000 \\
\hline $\mathrm{Na}_{2} \mathrm{O}$ & 7.72000 & 0.13000 \\
\hline $\mathrm{Fe}_{2} \mathrm{O}_{3}$ & 3.67000 & 0.09000 \\
\hline $\mathrm{MgO}$ & 1.43000 & 0.06000 \\
\hline $\mathrm{K}_{2} \mathrm{O}$ & 0.93700 & 0.04700 \\
\hline $\mathrm{CaO}$ & 0.79500 & 0.04000 \\
\hline $\mathrm{TiO}_{2}$ & 0.37400 & 0.01900 \\
\hline $\mathrm{SO}_{3}$ & 0.16300 & 0.00800 \\
\hline
\end{tabular}


XRF analysis test results of control sample was used Portland cement after $800{ }^{\circ} \mathrm{C}$ temperature exposure are given in Table 6.

Table 6. XRF analysis test results of the control sample

\begin{tabular}{|c|c|c|}
\hline Composition & $\mathrm{m} / \mathrm{m} \%$ & Standart error, $\%$ \\
\hline $\mathrm{SiO}_{2}$ & 64.33000 & 0.24000 \\
\hline $\mathrm{CaO}$ & 24.58000 & 0.22000 \\
\hline $\mathrm{Al}_{2} \mathrm{O}_{3}$ & 4.24000 & 0.10000 \\
\hline $\mathrm{Fe}_{2} \mathrm{O}_{3}$ & 2.01000 & 0.07000 \\
\hline $\mathrm{MgO}$ & 1.28000 & 0.06000 \\
\hline $\mathrm{SO}_{3}$ & 1.20000 & 0.05000 \\
\hline $\mathrm{K}_{2} \mathrm{O}$ & 1.03000 & 0.05000 \\
\hline $\mathrm{Na}_{2} \mathrm{O}$ & 0.53600 & 0.02700 \\
\hline
\end{tabular}

\section{CONCLUSION}

Following conclusions were made from the study:

Compressive strengths of class F fly ash based geopolymer mortar samples, subjected to initial curing at $50{ }^{\circ} \mathrm{C}, 60{ }^{\circ} \mathrm{C}$ and $70^{\circ} \mathrm{C}$ temperature, was not deteriorated after exposure to $800{ }^{\circ} \mathrm{C}$ temperature, contrary, they were increased. The compressive strength of geopolymer samples (F50) initially cured at $50{ }^{\circ} \mathrm{C}$ temperature was $7.63 \mathrm{MPa}$ before exposure to elevated $800{ }^{\circ} \mathrm{C}$ temperature, and it was $40.70 \mathrm{MPa}$ after exposure to elevated temperature. Geopolymer samples initially cured at lower temperatures showed higher resistance to elevated temperature than that of samples initially cured at higher temperatures.

Geopolymer mortar showed better performance than that of control ordinary cement mortar after exposure to elevated temperatures in terms of flexural and compressive strengths. This is supported by weight change data since weight loss of geopolymer mortar after exposure to elevated temperature was lower than that of corresponding cement mortar mixtures. SEM pictures of samples also supported that conclusion since it was observed that the inner structural disintegration were found to be less in the geopolymer samples when compared to control cement samples.

Finally, based on the laboratory study, it was concluded that geopolymer mortars made with class F fly ash can be utilized as construction materials in areas where it is to be exposed to elevated temperature.

\section{REFERENCES}

1. The Europen Cement Association, Activity Report. http://www.cembureau.be, 2014.

2. Taylor, M., Tam, C., Gielen, D. Energy Efficiency and $\mathrm{CO}_{2}$ Emissions from the Global Cement Industry, Energy Technology Policy Division International Energy Agency, Paris, 2006.

3. Atig, Cement industry report.

https://www.atig.com.tr/arastirma/raporlar/tr/cimento, 2015.

4. Benhelal, E., Gholomreza, Z., Ezzatlollah, S., Alireza, B. Global Strategies and Potentials to Curb $\mathrm{CO}_{2}$ Emissions in Cement Industry Journal of Cleaner Production 51 (15) 2013: pp. $142-161$. https://doi.org/10.1016/j.jclepro.2012.10.049

5. Bernal, S.A., Mejía de Gutiérrez, R., Pedraza, A.L., Provis, J.L., Rodriguez, E.D., Delvasto, S. Effect of Binder Content on the Performance of Alkali-Activated Slag
Concretes Cement and Concrete Research

2011: pp. $1-8$.

https://doi.org/10.1016/j.jclepro.2012.10.049

6. Slaty, F., Khoury, H., Wastiels, J., Rahier, H. Characterization of Alkali Activated Kaolinitic Clay, Applied Clay Science, Volumes 75-76 2013: pp 120-125 https://doi.org/10.1016/j.clay.2013.02.005

7. Aydın, S. Development of a Fiber Reinforced Composite with Alkali Activated Ground Granulated Blast Furnace Slag Dokuz Eylul University, The Graudate School of Naturel and Applied Science, Civil Engineering Department, $\mathrm{PhD}$ thesis, 2010.

8. Davidovits, J. Geopolymers and Geopolymeric New Materials Journal of Thermal Analysis 35 (2) 1989: pp. $429-441$ https://doi.org/10.1007/BF01904446

9. Zhang, Z.H., Zhu, H.J., Zhou, C.H., Wang, H. Geopolymer from Kaolin in China: An overview Applied Clay Science 119 2016: pp 31-41. https://doi.org/10.1016/j.clay.2015.04.023

10. Soutsos, M., Boyle, A.P., Vinai, R., Hadjierakleous, A., Barnett, S.J. Factors Influencing the Compressive Strength of Fly Ash Based Geopolymers Construction and Building Materials 110 2016: pp. 355-368. https://doi.org/10.1016/j.conbuildmat.2015.11.045

11. Monticelli, C., Criado, M., Fajardo, S., Bastidas, J.M, Abottoni, M., Balbo, A. Corrosion Behaviour of a Low Ni Austenitic Stainless Steel in Carbonated Chloride-Polluted Alkali-Activated Fly Ash Mortar Cement and Concrete Research 55 2014: pp. 49-58. https://doi.org/10.1016/j.cemconres.2013.09.014

12. Atis, C.D., Ilkentapar, S., Gorur, E.B., Karahan, O. Activated Fly Ash on Mechanical Properties of the mortar with alkali Geopolim the Effect of Heat Curing Time 9 th Concrete national congress Antalya, Turkey 16-18 2015: pp. 1-9.

13. Ma, Y., Ye, G. The Shrinkage of Alkali Activated Fly Ash Cement and Concrete Research 68 2015: pp. 75-82. https://doi.org/10.1016/j.cemconres.2014.10.024

14. Lizcano, M., Kim, H.S., Basu, S., Radovic, M. Mechanical Properties of Sodium and Potassium Activated MetakaolinBased Geopolymers Journal of Materials Science 47 2012: pp. $2607-2616$. https://doi.org/10.1007/s10853-011-6085-4

15. Leong, H.Y., Ong, D.E.L., Sanjayan, J.G., Nazari, A. The Effect of Different $\mathrm{Na}_{2} \mathrm{O}$ and $\mathrm{K}_{2} \mathrm{O}$ Ratios of Alkali Activator on Compressive Strength of Fly Ash Based-Geopolymer Construction and Building Materials 106 2016: pp. 500-511. https://doi.org/10.1016/j.conbuildmat.2015.12.141

16. Helmy, A.I.I. Intermittent Curing of Fly Ash Geopolymer Mortar Construction and Building Materials 110 2016: pp. $54-64$.

https://doi.org/10.1016/j.conbuildmat.2016.02.007

17. Petermann, J.C., Saeed, A., Hammons, M.I. AlkaliActivated Geopolymers: A Literature Review Air Force Research Laboratory Materials and Manufacturing Directorate Airbase Technologies Division, 2010.

18. Özodabaş, A., Yılmaz, K. Improvement of the Performance of Alkali Activated Blast Furnace Slag Mortars with Very Finely Ground Pumice Construction and Building Material 48 2013: pp. 26-34. https://doi.org/10.1016/j.conbuildmat.2013.06.047

19. Balcikanli, M., Ozbay, E. Optimum Design of Alkali 
Activated Slag Concretes for the Low Oxygen/Chloride Ion Permeability and Thermal Conductivity Composites Part B: Engineering 91 2016: pp. 243-256. https://doi.org/10.1016/j.compositesb.2016.01.047

20. Kaya, M. Examination of Mechanical and Durability Properties of Various Types of Fly Ash Produced by Using Alkali Activated Mortars Sakarya University, The Graudate School of Naturel and Applied Science, Civil Engineering Department, $\mathrm{PhD}$ thesis, 2016.

21. Mahboob, S. Development of Low Carbon and Low Energy Geopolymer-based Cement Free Construction Materials Department of Civil Engineering, Brunel University, PhD Thesis, 2014.

22. Shi, X.S., Collins, F.G., Zhao, X.L., Wang, Q.Y. Mechanical Properties and Microstructure Analysis of Fly Ash Geopolymeric Recycled Concrete Journal of Hazardous Materials 30 2012: pp. 20-29

https://doi.org/10.1016/j.jhazmat.2012.07.070

23. Rangan, B.V. Fly Ash-Based Geopolymer Concrete Research Report GC 4, Engineering Faculty, Curtin University of Technology SF:44, Perth, Australia, 2008.

24. Komljenovic, M., Bascarivic, Z., Bradic, V. Mechanical and Microstructural Properties of Alkali-Activated Fly Ash Geopolymers Journal of Hazardous Materials 181 2010: pp. $35-42$. https://doi.org/10.1016/j.jhazmat.2010.04.064

25. Bignozzi, M.C., Manzi, S., Natali, M.E., Rickard, W.D.A., Riessen, A. Room temperature Alkali Activation of Fly Ash: The Effect of $\mathrm{Na}_{2} \mathrm{O} / \mathrm{SiO}_{2}$ Ratio Construction and Building Materials 69 2014: pp. 262-270.

https://doi.org/10.1016/j.conbuildmat.2014.07.062

26. Junaid, M.T., Kayali, O., Khennane, A., Black, J. A Mix Design Procedure for Low Calcium Alkali Activated Fly AshBased Concretes Construction and Building Materials 79 2015: pp. $301-310$.

https://doi.org/10.1016/j.conbuildmat.2015.01.048

27. Ducman, V., Korat, L. Characterization of Geopolymer FlyAsh Based Foams Obtained with the Addition of Al Powder or $\mathrm{H}_{2} \mathrm{O}_{2}$ as Foaming Agents Materials Characterization 113 2016: pp. $207-213$. https://doi.org/10.1016/j.matchar.2016.01.019

28. Görür, E.B. Investigate the Strength and Durability Characteristics of Fly Ash Geopolymer Concrete with Alkaly. Erciyes University, The Graudate School of Naturel and Applied Science, Civil Engineering Department, $\mathrm{PhD}$ thesis, 2015.

29. Zhu, H., Zuhang, Z., Zhu, Y., Tian, L. Durability of AlkaliActivated Fly Ash Concrete: Chloride Penetration in Pastes and Mortars Construction and Building Materials 65 2014: pp. $51-59$.

https://doi.org/10.1016/j.conbuildmat.2014.04.110

30. Dombrowski, K., Buchwald, A., Weil, M. The Influence of Calcium Content on the Structure and Thermal Performance of Fly Ash Based Geopolymers Journal of Materials Science 42 (9) 2007: pp. 3033-3043.

31. Pan, Z., Tao, Z., Murphy, T., Wuhrer, R. High Temperature Performance of Mortars Containing Fine Glass Powders Journal of Cleaner Production 162 2017: pp. $16-26$.

https://doi.org/10.1016/j.jclepro.2017.06.003
32. Sarker, P.K., McBeath, S. Fire Endurance of Steel Reinforced Fly Ash Geopolymer Concrete Elements Construction and Building Materials 90 2015: pp. 91-98. https://doi.org/10.1016/j.conbuildmat.2015.04.054

33. Zhang, H.Y., Kodur, V., Wu, B., Cao, L., Wang, F. Thermal Behavior and Mechanical Properties of Geopolymer Mortar After Exposure to Elevated Temperatures Construction and Building Materials 109 2016: pp. 17-24. https://doi.org/10.1016/j.conbuildmat.2016.01.043

34. ASTM C 618, Standard Specification for Coal Fly Ash and Raw or Calcined Natural Pozzolan for Use in Concrete.

35. TS EN 197-1: 2012 General Cement-Composition, Specifications and Conformity Criteria.

36. TS EN 196-1: 2016 Methods of Testing Cement-Part 1: Determination of Strength.

37. TS EN 1250-4 Concrete Tests - Part 4: Determination of Ultrasonic Pulsed Wave Velocity.

38. TS EN 1363-2 Fire Resistance Experiment Standards-Part 2: Alternative and Additional Procedures.

39. TS EN 1015-11 Methods of Test for Mortar for Masonry-Part 11: Determination of Flexural and Compressive Strength of Hardened Mortar.

40. Fernández-Jiménez, A., Palomo, A., Pastor, J., Martin, A. New Cementitious Materials Based on Alkali-Activated Fly Ash: Performance at High Temperatures Journal of the American Ceramic Society 91 (10) 2008: pp. 3308-3314. https://doi.org/10.1111/j.1551-2916.2008.02625.x

41. Shaikh, F.U.A., Vimonsatit, V. Compressive Strength of Fly-Ash-Based Geopolymer Concrete at Elevated Temperatures Fire and Materials 39 (2) 2015: pp. $174-188$ https://doi.org/10.1002/fam.2240

42. Luga, E. Properties of Fly Ash and Blast Furnace Slag Geopolymer Mortars Erciyes University, The Graudate School of Naturel and Applied Science, Civil Engineering Department, PhD thesis, 2015.

43. Tanyıldızı, H., Yonar, Y. Mechanical Properties of Geopolymer Concrete Containing Polyvinyl Alcohol Fiber Exposed to High Temperature Construction and Building Materials 126 2016: pp. 381-387. https://doi.org/10.1016/j.conbuildmat.2016.09.001

44. Kong, D.L.Y., Sanjayan, J.G., Sagoe-Crentsil, K. Comparative Performance of Geopolymers Made with Metakaolin and Fly Ash After Exposure to Elevated Temperatures Cement and Concrete Research 37 2007: pp. $1583-1589$. https://doi.org/10.1016/j.cemconres.2007.08.021

45. Shaikh, F.U.A., Vimonsatit, V. Compressive Strength of Fly-Ash-Based Geopolymer Concrete at Elevated Temperatures Fire and Materials $39(2)$ 2015 pp: $174-188$. https://doi.org/10.1002/fam.2240

46. Gao, K., Lin, K.L., Wang, D., Hwang, C.L., Tuan, B.L.A., Shiu, H.S., Cheng, T.W. Effect of $\mathrm{Nano}^{-\mathrm{SiO}_{2}}$ on the AlkaliActivated Characteristics of Metakaolin-based Geopolymers Construction and Building Materials 48 2013: pp. $441-447$. https://doi.org/10.1016/j.conbuildmat.2013.07.027 